\title{
PENERAPAN INOVASI KONDISI PEMBELAJARAN DAN DISIPLIN KINERJA GURU SEBAGAI PENGARUH DALAM PERSEPSI KEPEMIMPINAN SEKOLAH, IKLIM ORGANISASI DAN ALTRUISTIK DI LINGKUNGAN SMA NEGERI 1 SIBOLGA, KABUPATEN SIBOLGA
}

\author{
Ali Sutan Lubis \\ Sekolah Menengah Atas Negeri 1 Sibolga \\ alisutanlubis@gmail.com
}

\begin{abstract}
Abstrak: Penelitian ini bertujuan untuk mengetahui pengaruh persepsi kepemimpinan kepala sekolah terhadap altruistik, pengaruh iklim organisasi terhadap altruistik, persepsi kepemimpina kepala sekolah terhadap disiplin kerja guru, pengaruh iklim organisasi terhadap disiplin kerja guru, dan pengaruh altruistik terhadap disiplin kerja guru. Jenis Penelitian ini menggunakan penelitian kuantitatif dengan pendekatan analisi jalur dengan responden guru di SMA Negeri 1 Sibolga dengan teknik sampling Stratified Proportional Random Sampling. Pengumpulan data dilakukan menggunakan angket..Angket yang digunakan terlebih dahulu dilakukan ujicoba untuk mendapatkan instrument yang valid dan reliabel. Sebelum dilakukan ujicoba instrument dilakukan uji persyaratan analisis sebagai persyratan analisis jalur, yaitu uji normalitas dan uji linieritas. Hasil temuan penelitian adalah terdapat terdapat pengaruh langsung positif persepsi terhadap kepemimpina kepala sekolah terhadap altruistik. Terdapat pengaruh langsung positif antara iklim organisasi terhadap altruistik. Terdapat pengaruh langsung positif persepsi terhadap kepemimpinan kepala sekolah terhadap disiplin kerja guru. Terdapat pengaruh langsung positif antara iklim organisasi terhadap disiplin kerja guru. Terdapat pengaruh pengaruh langsung positif antara altruistik terhadap disiplin kerja guru. Teтuan penelitian ini menyimpulkan untuk meningkatkan Disiplin kerja guru dapat dilakukan dengan meningkatkan persepsi terhadap kepemimpinan kepala sekolah, iklim organisasi dan altruistik guru. Besar pengaruh ketiga variabel eksogen, yaitu persepsi terhadap kepemimpinan kepala sekolah, iklim organisasi dan altruistic guru sebesar 25,30\% terhadap variabel endogennya, yaitu Disiplin Kerja.
\end{abstract}

Kata Kunci: persepsi, kepemimpinan, kepala sekolah, iklim organisasi, altruistik, disiplin kinerja

\begin{abstract}
This study aims to determine the influence of the principal's leadership perceptions on altruistics, the influence of the organization's climate on altruistics, the perception of the principal's leadership on teacher work disciplines, the influence of the organization's climate on teacher work discipline, and the altruistic influence on teacher work discipline.This type of research uses quantitative research with a path analysis approach with teacher respondents at Sma Negeri 1 Sibolga with Stratified Proportional Random Sampling sampling technique.Data collection is done using questionnaires.. The questionnaire used first was tested to obtain a valid and reliabel instrument.Prior to the instrument test, the analysis requirements were conducted as a test of the analysis of the path, namely the normality test and the linearity test. The findings of the study are that there is a positive direct influence of perception on the principal's leadership on altruistics.There is a positive direct influence between the organization's climate and altruistic. There is a positive direct influence on the principal's leadership on the discipline of the teacher's work.There is a positive direct influence between the organization's climate on teacher work discipline.There is a positive direct influence between altruistic and teacher discipline.The findings of this study conclude to improve teacher work discipline can be done by improving perception of principal leadership, organizational climate and altruistic teachers.The large influence of the three exogenous variables, namely the perception of the principal's leadership, organizational climate and altruistic teachers amounted to $25.30 \%$ against its endogenous variable, namely Work Discipline.Keywords: perception, leadership, principal, organizational climate, altruistic, performance discipline.
\end{abstract}

Keywords: learning strategies, mind maps, expository, office technology

\section{PENDAHULUAN}

Masalah yang terjadi di lapangan masih ditemukan adanya guru yang tidak bisa memperhatikan berbagai persoalan baik menyangkut peserta didik, subject matter, maupun metode pembelajaran, sehingga guru kurang mamahami untuk memecahkan permasalahan nyata yang terjadi di dalam kelas sekaligus mencari jawaban ilmiah mengapa hal tersebut dapat dipecahkan melalui tindakan yang akan dilakukan, hal ini peneliti temui pada saat mengadakan supervisi akademik (supervisi 
kunjungan kelas) pada sekolah binaan.

Berbagai usaha yang telah dan sedang dilakukan pemerintah sampai saat ini dimaksudkan untuk meningkatkan mutu pendidikan, antara lain melalui upaya penyempurnaan kurikulum, pengadaan sarana dan prasarana belajar, meningkatkan jumlah anggaran pendidikan, rekrutmen guru dan peningkatan profesionalisme dalam bentuk seminar, pelatihan, workshop, terbukanya peluang untuk mengikuti pendidikan.

Tidak sampai di situ saja, program pembinaan bagi semua guru telah pula dilakukan pemerintah melalui dinas terkait yang dimaksdukan untuk meningkatkan soft skill dan kedisiplinan guru. Misalnya, program bimbingan teknis dan bimbingan mental yang diselenggarakan sekolah dengan supervisi dari dinas pendidikan telah berlangsung sampai saat ini. Sebab betapa pun hebatnya penyempurnaan kurikulum, pengadaan sarana dan prasarana belajar yang serba canggih, peningkatan jumlah anggaran pendidikan yang besar, rekrutmen guru dan peningkatan profesionalisme dalam bentuk seminar, pelatihan, workshop, terbukanya peluang untuk mengikuti pendidikan serta program sertifikasi guru belum berarti apa-apa apabila tidak diimbangi dengan peningkatan soft skill dan kedisiplinan guru.

Berdasarkan pada pernyataan tersebut di atas dapat dinyatakan bahwa kedisiplinan guru sangat penting untuk menghasilkan sistem pembelajaran yang berkualitas. Begitu pentingnya aspek kedisiplinan ini, Nicholas Odoyo Simba, John Odwar Agak \& Eric K. Kabuka, menyatakan sebagai berikut:

"Researchers appreciate that discipline is an important component of human behavior and assert that without it an organization cannot function well towards the achievement of its goals (Ouma, Simatwa, \& Serem, 2013). In the context of a school system, a disciplined student is that student whose behaviours, actions and inactions conform to the predetermined rules and regulations of the school (Ali, Dada, Isiaka, \& Salmon, 2014)."

Berdasarkan hasil observasi dan studi dokumen yang dilakukan di SMA Negeri 1 Sibolga, ditemukan delapan kebiasaan yang sering dilakukan yang menunjukkan lemahnya kedisiplinan guru dalam melaksanakan tugas pembelajaran, yaitu: (1) Kehadiran di sekolah yang selalu tidak tepat waktu, termasuk pada jam mengajar di kelas. (2) Rendahnya pemahaman tentang strategi pembelajaran. (3)
Tanggungjawab yang diberikan kepada guru belum sepenuhnya dilaksanakan dengan baik, misalnya kelengkapan perangkat pembelajaran seperti RPP dan silabus yang kebanyakan masih mengganti tahun ajaran tanpa melakukan revisi yang mendalam, misalnya analisis terhadap aktivitas guru, aktivitas siswa, kesesuaian metode, media dan evaluasi yang digunakan. (4) Kurangnya keterampilan dalam mengelola kelas. Secara umum banyak masih ditemukan proses pembelajaran berlangsung di bawah kontrol dan pembinaan guru secara ketat. (5) Rendahnya kemampuan melakukan dan memanfaatkan penelitian tindakan sekolah, (6) Rendahnya keinginan untuk motivasi berprestasi. (7) Rendahnya komitmen profesi, dan (8) Rendahnya kemampuan dalam manajemen waktu.

Dengan demikian, dapat dikatakan bahwa rendahnya perolehan nilai ujian nasional disebabkan oleh rendahnya disiplin guru. Keadaan ini berbanding lurus dengan keadaan guru di SMA Negeri 1 Sibolga yang belum memaksimalkan pelaksanaan tugas-tugasnya. Sejelan dengan hal tersebut, Dinas Pendidikan Sumatera Utara menyusun program kerja tahun 2018 bidang pembinaan dan ketenagaan yang berfungsi untuk meningkatkan kedisiplinan guru, antara lain: penguatan Musyawarah Guru Mata Pelajaran (MGMP), Musyawarah Kerja Kepala Sekolah (MKKS), dan Musyawarah Kerja Pengawas Sekolah (MKPS). MGMP dan KKG adalah organisasi profesi guru non struktural yang dibentuk oleh guru dan untuk guru serta keanggotaannya secara otomatis. MGMP dan KKG ini berfungsi sebagai:

a. Menumbuhkan gairah dan keinginan guru untuk meningkatkan kemampuan dan keterampilan dalam merencakan, melaksanakan, dan penialaian di kelas.

b. Mendiskusikan permasalahan yang dihadapi guru dalam melaksanakan tugas sehari-hari dan menemukan cara pemecahannya sesuai dengan karakteristik mata pelajaran.

c. Memberi kesempatan kepada guru untuk membagi informasi dan pengalaman dan dalam rangka penetapan kurikulum dan perkembangan IPTEK dan kebijakan pendidikan.

d. Memberi kesempatan kepada para guru untuk menuangkan ide-ide kreatifnya melalui program dan kegiatan KKG dan MGMP. 
e. Membangun kerjasama dengan semua pihak untuk menciptakan proses pembelajaran yang efektif dan menyenangkan.

Sementara itu, dari studi awal terhadap berbagai permasalahan guru dalam konteks kedisiplinan di SMA Negeri 1 Sibolga, dapat dikemukakan beberapa fakta. Pertama, kurang lengkapnya perencanaan pembelajaran yang disusun oleh guru. Kedua, guru tidak rutin dalam menyusun Rencana Pelaksanaan Pembelajaran (RPP). Ketiga, pembelajaran yang dilaksanakan oleh guru kurang sesuai dengan Rencana Pelaksanaan Pembelajaran (RPP) yang disusun. Keempat, sebagian guru menyusun perencanaan pembelajaran ketika akan disupervisi oleh kepala sekolah atau Pembina. Kebijakan pemerintah mengenai pemberlakuan Kurikulum Tingkat Satuan Pendidikan adalah sejalan dan dilandasi paradigma baru pengelolaan pendidikan yang memberikan otonomi kepada sekolah. Sekolah sesuai dengan kondisinya, potensi siswa, dan potensi daerah dalam batas-batas tertentu diberi keleluasaan untuk mengembangkan kurikulumnya sendiri. Sekolah diharapkan dapat melakukan analisis kekuatan dan kelemahan yang dimiliki, serta peluang dan ancaman yang dihadapi. Dari sini mereka bersama-sama dengan stakeholdernya dapat membuat benchmarking yang tidak harus sama dengan sekolah di tempat lain.

\section{Hakikat Disiplin Kerja}

Disiplin pegawai dalam manajemen sumberdaya manusia berangkat dari pandangan bahwa tidak ada manusia yang sempurna, luput dari kekhilafan dan kesalahan. Oleh karena itu setiap organisasi perlu memiliki berbagai ketentuan yang harus ditaati oleh para anggotanya, standar yang harus dipenuhi. Dengan kata lain disiplin pegawai adalah suatu bentuk pelatihan yang berusaha bekerja secara kooperatif dengan para karyawan yang lain serta meningkatkan prestasi kerjanya. Menurut Siagian (2008), dikatakan bahwa terdapat dua jenis disiplin dalam organisasi, yaitu yang bersifat preventif dan korektif.

a. Pendisiplinan Preventif

Pendisiplinan yang bersifat preventif adalah tindakan yang mendorong para karyawan untuk taat kepada berbagai ketentuan yang berlaku dan memenuhi standar yang telah ditetapkan. Artinya melalui kejelasan dan penjelasan tentang pola sikap, tindakan dan perilaku yang diinginkan dari setiap anggota organisasi diusahakan pencegahan jangan sampai para karyawan berperilaku negatif.

b. Pendisiplinan Korektif

Berdasarkan pada kajian literatur tentang kedisiplinan ditemukan beberapa rumusan/definisi berkaitan dengan disiplin dan kinerja, antara lain: Fathoni (2009), menyatakan bahwa disiplin adalah kesadaran dan kesediaan seseorang menaati semua peraturan dan normanorma sosial yang berlaku. Sedangkan Simamora (2006), menyatakan bahwa disiplin adalah prosedur yang mengoreksi atau menghukum bawahan karena melanggar peraturan atau prosedur. Disiplin merupakan bentuk pengendalian diri karyawan dan pelaksanaan yang teratur serta menunjukkan tingkat kesungguhan tim kerja di dalam suatu organisasi.

Singodimedjo dalam Sutrisno (2013), menyatakan bahwa disiplin adalah sikap kesediaan dan kerelaan seseorang untuk mematuhi dan menaati norma-norma peraturan yang berlaku di sekitarnya. Disiplin adalah sikap kesediaan dan kerelaan seseorang untuk mematuhi dan menaati segala norma peraturan yang berlaku di organisasi. Disiplin sangat diperlukan baik individu yang bersangkutan maupun oleh organisasi. Contoh, seorang pesuruh di sebuah kantor yang terlambat datang, akibatnya ruangan kerja di kantor tersebut semuanya terkunci, sehingga kegiatan di kantor tersebut menjadi terganggu, karena tidak ada pegawai yang dapat melakukan aktivitasnya, sehingga mengganggu proses operasi di hari itu. Berdasarkan contoh tersebut dapat kita lihat bahwa ketidakdisiplinan seorang dapat merusak aktivitas organisasi.

\section{Tujuan dan Manfaat Disiplin}

Menurut Simamora dalam Sinambela (2012), menyatakan bahwa tujuan utama tindakan pendisiplinan adalah memastikan bahwa perilaku-perilaku pegawai konsisten dengan aturan-aturan yang ditetapkan oleh organisasi. Berbagai aturan yang disusun oleh organisasi adalah tuntunan untuk mencapai tujuan organisasi yang ditetapkan. Pada saat suatu aturan dilanggar, efektivitas organisasi berkurang sampai pada tingkat tertentu, tergantung pada kerasnya pelanggaran.

Tujuan berikutnya adalah menciptakan atau mempertahankan rasa hormat dan saling percaya diantara atasan dan bawahannya. Disiplin yang diberlakukan secara tidak tepat 
dapat menciptakan masalah-masalah seperti moral kerja yang rendah, kemarahan, dan kemauan buruk di antara Pembina dan bawahan-bawahannya. Dalam kondisi seperti ini semua perbaikan dan perilaku pegawai hanya akan berlangsung singkat, dan Pembina harus mendisiplinkan kembali pegawai dalam jangka waktu yang tidak terlalu lama. Pelaksanaan tindakan disiplin yang benar tidak hanya memperbaiki perilaku pegawai, akan tetapi juga akan meminimalkan masalahmasalah pendisiplinan di masa yang akan datang melalui hubungan yang positif di antara bawahan dan atasan.

\section{Urgensi Disiplin Kerja Guru}

Diungkapkan oleh Sutrisno (2013), bahwa disiplin kerja sangat diperlukan untuk menunjang kelancaran segala aktifitas organisasi agar tujuan organisasi dapat dicapai secara maksimal. Disiplin kerja dapat dilihat sebagai sesuatu yang besar manfaatnya, baik bagi kepentingan organisasi maupun kepentingan pegawai. Bagi organisasi adanya disiplin kerja akan menjamin terpeliharanya tata tertib dan kelancaran pelaksanaan tugas, sehingga diperoleh hasil yang optimal. Adapun bagi pegawai akan diperoleh suasana kerja yang menyenangkan sehingga akan menambah semangat kerja dalam melaksanakan pekerjaannya.

\section{Persepsi Terhadap Kepemimpinan Kepala Sekolah}

Dalam praktik organisasi, kata memimpin mengandung konotasi menggerakkan, mengarahkan, membimbing, melindungi, membina, memberikan teladan, memberikan dorongan, memberikan bantuan, dan sebagainya. Betapa banyak variabel arti yang terkandung dalam kata memimpin, memberikan indikasi betapa luas tugas dan peranan seorang pemimpin organisasi (Stogdill, 1974)

Terry (1983), mendefinisikan kepemimpinan adalah hubungan di mana satu orang yakni pemimpin mempengaruhi pihak lain untuk bekerjasama secara sukarela dalam usaha mengerjakan tugas-tugas yang berhubungan untuk mencapai hal yang diinginkan oleh pemimpin tersebut. Kepemimpinan merupakan proses mempengaruhi orang lain untuk mencapai tujuan, sebagaimana yang dikemukakan Hersey \& Blanchard (1988), "leadership is the activity of influencing people to strive willingly for group objectives". Kepemimpinan tidak hanya ada pada organisasi tapi di manapun proses mempengaruhi orang lain sudah dikatakan dengan kepemimpinan.

Selanjutnya, Nur (1995), memberikan pengertian bahwa kepemimpinan merupakan suatu proses atau setiap usaha, kapan saja, untuk mempengaruhi sikap dan prilaku orang lain, perorangan atau kelompok, tanpa harus dibatasi oleh suatu konteks organisasi demi tercapainya suatu maksud. Baik itu maksud perorangan maupun tujuan kelompok atau organisasi, dan tercapainya tujuan-tujuan dengan cara yang penuh pengertian dan sukarela. Dengan demikian kepemimpinan adalah kemampuan mendorong sejumlah orang (dua orang atau lebih) agar bisa bekerjasama dalam melaksanakan kegiatan-kegiatan yang terarah pada tujuan bersama. Anoraga (2001), menjelaskan kepemimpinan adalah kemampuan seseorang untuk mempengaruhi orang lain, melalui komunikasi baik langsung maupun tidak langsung dengan maksud untuk menggerakkan orang-orang tersebut agar dengan penuh pengertian, kesadaran dan senang hati bersedia mengikuti kehendak-kehendak kepemimpinan itu. Selanjutnya Sutisna (1983), mengemukakan bahwa kepemimpinan adalah suatu proses mempengaruhi kegiatan seseorang atau kelompok dalam usaha ke arah pencapaian tujuan dalam situasi tertentu. Mintorogo (1996), melihat kepemimpinan sebagai kemampuan seseorang untuk mempengaruhi perilaku orang lain, sehingga orang tersebut mau mengikuti kehendaknya dengan sadar, rela, dan sepenuh hati.

Pendekatan sifat (the trait approach). Pendekatan ini menekankan pada kualitas pemimpin. Keberhasilan pemimpin ditandai oleh daya kecakapan luar biasa yang dimiliki oleh pemimpin, seperti tidak kenal lelah, intuisi yang tajam, wawasan masa depan yang luas, dan kecakapan meyakinkan yang sangat menarik. Menurut pendekatan sifat, seseorang menjadi pemimpin karena sifat-sifatnya yang dibawa sejak lahir, bukan karena dibuat atau dilatih. Seperti dinyatakan Purwanto (1997), menyatakan bahwa pemimpin dilahirkan bukan dibuat bahwa pemimpin tidak dapat memperoleh kemampuan untuk memimpin, tetapi mewarisinya. Selanjutnya Sutisna (1983), mengemukakan bahwa seseorang tidak menjadi pemimpin dikarenakan memiliki suatu kombinasi sifat-sifat kepribadian, tapi pola 
sifat-sifat pribadi pemimpin itu mesti menunjukan hubungan tertentu dengan sifat, kegiatan dan tujuan dari pada pengikutnya. Berdasarkan pendekatan sifat, keberhasilan seorang pemimpin tidak hanya dipengaruhi oleh sifat-sifat pribadi, melainkan ditentukan pula oleh keterampilan (skill) pribadi pemimpin. Hal ini sejalan dengan pendapat Yukl (2009), yang menyatakan bahwa sifat-sifat pribadi dan keterampilan seseorang pimpinan berperan dalam keberhasilan seorang pemimpin.

Lebih lanjut, Yukl (2009), menjelaskan bahwa pendekatan situasional menekankan pada pentingnya faktor-faktor kontekstual seperti sifat pekerjaan yang dilaksanakan oleh unit pimpinan, sifat lingkungan eksternal, dan karakteristik para pengikut. Sementara Fattah (2001), berpandangan bahwa keefektifan kepemimpinan bergantung pada kecocokan antara pribadi, tugas-tugas yang dilaksanakan, kekuasaan, sikap, dan persepsi dari masingmasing personal.

Berkaitan dengan uraian di atas, Suradinata (1997:26), menyatakan bahwa pemimpin suatu organisasi yang sukses harus memiliki beberapa syarat, yaitu: (1) mempunyai kecerdasan yang lebih, untuk memikirkan dan memecahkan setiap persoalan yang timbul dengan tepat dan bijaksana, (2) mempunyai emosi yang stabil, tidak mudah diombang ambing oleh suasana yang berganti, dan dapat memisahkan persoalan pribadi, rumah tangga, dan organisasi, (3) mempunyai keahlian dalam menghadapi manusia serta bisa membuat bawahan menjadi senang dan merasa puas, (4) mempunyai keahlian untuk mengorganisir dan menggerakkan bawahannya dengan kebijaksanaan dalam mewujudkan tujuan organisasi, umpamanya tahapan bila dan kepada siapa tanggung jawab dan wewenang akan diserahkan, dan (5) kondisi fisik yang sehat dan kuat.

Kepemimpinan kepala sekolah seyogyanya dapat mempengaruhi orang lain seperti guru dan personil sekolah untuk mencapai tujuan yang diinginkan. Tujuan akan tercapai jika kepala sekolah mau dan mampu membangun komitmen dan bekerja keras untuk menjadikan sekolah yang dipimpinnya menjadi sekolah yang berkualitas dan menjadi yang terbaik di daerahnya. Realitas yang berkembang saat ini menunjukkan bahwa efektivitas kepemimpinan berubah berdasarkan faktor yang ada pada satu situasi kepemimpinan. Penelitian Davis (2005) menyebutkan profil pimpinan efektif yang dikehendaki oleh 500 orang karyawan dalam penelitian tersebut, meliputi: (1) Kebutuhan pimpinan yang baik, (2) ingin mendapatkan penjelasan, dan mengetahui tujuan yang ingin dicapai organisasi, (3) membutuhkan pimpinan yang mampu memotivasi untuk maju dan membutuhkan iklim kompetitif mencapai jenjang kemajuan, (4) ingin kebebasan dalam sikap sehubungan dengan masalah pekerjaan, (5) ingin hidup rukun bermasyarakat dan ingin penghormatan dari orang lain, (6) jaminan keamanan, (7) ingin kondisi kerja yang menyenangkan, (8) ingin melakukan pekerjaan yang bermanfaat, (9) ingin diperlakukan secara jujur.

Berdasarkan faktor-faktor tersebut, maka jelaslah bahwa kesuksesan pemimpin dalam aktivitasnya dipengaruhi oleh faktorfaktor yang dapat menunjang untuk berhasilnya suatu kepemimpinan. Oleh sebab itu suatu tujuan akan tercapai apabila terjadinya keharmonisan dalam hubungan atau interaksi yang baik antara atasan dan bawahan, di samping dipengaruhi oleh latar belakang yang dimiliki pemimpin, seperti motivasi untuk berprestasi, kedewasaan dan keleluasaan dalam hubungan sosial dengan sikap hubungan manusiawi.

\section{Kompetensi Utama Kepala Sekolah}

Kepala sekolah merupakan pimpinan tertinggi (top leader) dalam suatu lembaga pendidikan formal. Sehingga kepala sekolah dapat dikatakan sebagai ujung tombak atas maju mundurnya lembaga pendidikan yang dipimpinnya. Kepala sekolah dalam melaksanakan tugasnya harus dibekali dengan berbagai kemampuan dan keterampilan yang mendukung kepemimpinannya itu. Tuntutan agar seorang kepala sekolah memiliki kemampuan, keterampilan dan kompetensi terasa semakin mutlak diperlukan mengingat peran serta fungsi kepala sekolah tersebut sangat besar untuk meningkatkan kualitas dan pelayanan pendidikan. Dalam mendukung tercapainya tujuan tersebut, kepala sekolah perlu dibekali dengan dua kompetensi, yaitu: (1) kompetensi utama, dan (2) kompetensi penunjang (Depdiknas, 2005).

\section{Iklim Organisasi Guru}

Iklim organisasi sekolah yang baik akan memberikan dorongan motivasi 
berprestasi kepada setiap individu yang ada di dalam struktur organisasi tersebut harus dapat bekerja dengan nyaman. Newstrom \& Davis, (2002) menyatakan bahwa: "organization climate is the human environment within an organization's employess do their work". (Maksudnya adalah iklim organisasi itu adalah yang menyangkut semua lingkungan yang ada atau yang dihadapi oleh manusia di dalam suatu organisasi tempat mereka melaksanakan pekerjaannya).

Gibson (2003), menyatakan bahwa iklim organisasi sebagai studi persepsi individu mengenai berbagai aspek lingkungan organisasinya. Unsur-unsurnya dapat dipersepsikan dan dialami oleh anggota organisasi yang gambarannya dapat diperoleh melalui penyusunan kuesioner yang tepat.

Robbins (2001), menyatakan bahwa, "organization climate is s set of properties of the work environment perceived directly or indirectly by the employees who work in this environment and is assumed to be a major force in influencing their behavior on the job." (iklim organisasi merupakan satu set perlengkapan dari suatu lingkungan kerja yang dirasakan secara langsung atau tidak langsung oleh karyawan yang bekerja di lingkungan ini dan beranggapan akan menjadi kekuatan utama yang mempengaruhi tingkah laku mereka).

Iklim organisasi terdiri dari hubungan antar karyawan dan kombinasi antara nilai dan tujuan yang ditetapkan oleh perusahaan. Hal ini sejalan dengan pendapat Steers (1995), menyatakan bahwa iklim organisasi merupakan lingkungan internal yang mewakili faktor-faktor dalam organisasi yang menciptakan kultur dan lingkungan sosial di mana aktivitas-aktivitas pencapaian tujuan berlangsung.

Menurut Handoko (2003), menyatakan ada enam dimensi iklim organisasi yaitu: flexibility conformity, resposibility, standards, reward, clarity, dan tema commitment. Selanjutnya Litwin \& Stringers (1992), menyatakan bahwa dimensi iklim organisasi terdiri: (1) rasa tanggungjawab, (2) standard atau harapan tentang kualitas pekerjaan, (3) ganjaran atau reward, (4) rasa persaudaraan, dan (5) semangat.

Robbins (2004), menyatakan bahwa ada dua tipe iklim organisasi, yaitu: (1) iklim organisasi terbuka, mencakup semangat kerja karyawan sangat tinggi, dorongan pimpinan untuk memotivasi karyawannya agar berprestasi sangat besar; sedangkan rutinitas administrasi rendah, karyawan yang meninggalkan pekerjaan seperti bolos, ijin dan sebagainya juga rendah, perasaan terpaksa untuk bekerja juga rendah, (2) iklim organisasi tertutup mencakup, semangat kerja karyawan sangat rendah, dorongan pimpinan untuk memotivasi karyawannya berprestasi sangat rendah, sedangkan rutinitas administratif tinggi, karyawan yang meninggalkan pekerjaan tinggi, perasaan terpaksa untuk bekerja juga tinggi.

Dengan demikian dapat disimpulkan bahwa iklim organisasi sekolah merupakan Penilaian/Umpan Balik dari nilai-nilai umum, etika, norma sikap, tingkah laku dan perasaan guru terhadap organisasi sekolah. Hal ini akan ditandai dengan: (1) Standar kerja guru yang dinamis, (2) interaksi positif antara struktur organisasi sekolah, (3) kepemimpinan kepala sekolah yang mendukung, (4) rasa persaudaraan dan kekeluargaan guru yang positif, serta (5) partisipasi aktif guru dalam organisasi sekolah. Kelima hal di atas selanjutnya ditetapkan sebagai indikator penelitian untuk mendapatkan data tentang iklim organisasi.

\section{Altruistik Dalam Perspektif Pendidikan}

Altruisme adalah perhatian terhadap kesejahteraan orang lain tanpa memperhatikan diri sendiri. Perilaku ini merupakan kebajikan yang ada dalam banyak budaya dan dianggap penting oleh beberapa agama. Gagasan ini sering digambarkan sebagai aturan emas etika. Beberapa aliran filsafat, seperti objektivisme berpendapat bahwa altruisme adalah suatu keburukan. Altruisme adalah lawan dari sifat egois yang mementingkan diri sendiri. Lawan dari altruisme adalah egoisme.

Namun, pada masa globalisasi saat ini masyarakat di kota-kota besar Indonesia sedikit demi sedikit mengalami perubahan sebagai akibat dari modernisasi. Jadi, tidaklah mengherankan apabila di kota-kota besar nilainilai pengabdian, kesetiakawanan dan tolongmenolong mengalami penurunan sehingga yang nampak adalah perwujudan kepentingan diri sendiri dan rasa individualis (Sarwono dan Meinarno, 2009).

Perilaku menolong disebut juga altruisme. Menurut Myers (2000) altruisme adalah perilaku menolong orang lain tanpa pamrih. Perilaku itu bukan saja tidak mengharapkan balas jasa, tetapi juga tidak memiliki tujuan-tujuan pribadi tertentu (self interest). Bantuan itu diberikan secara tulus, sepenuh hati dan tidak memilih siapa yang akan 
dibantu.

Banyak faktor yang dapat mempengaruhi altruisme salah satunya yaitu konformitas. Menurut Sarwono dan Meinarno (2009) konformitas adalah kesesuaian antara perilaku seseorang dengan perilaku orang lain yang di dorong oleh keinginannya sendiri. Konformitas merupakan salah satu faktor yang dapat mempengaruhi altruisme. menurut Watson at. al (1999) karakteristik hubungan interpersonal meliputi sifat kesamaan, kedekatan hubungan dan daya tarik merupakan konformitas.

Hurlock (2006) mengatakan bahwa pada dasarnya manusia mempunyai sifat prososial seperti menolong, membagi perhatian atau peduli terhadap keberadaan orang lain. Mungkin memang benar demikian adanya namun tidak semua orang mempunyai altruisme dengan kualitas yang sama. Perbedaan kualitas tersebut banyak ditentukan oleh proses belajar, lingkungan dan kepribadian. Banyak faktor yang dapat mempengaruhi altruisme salah satunya yaitu konformitas. Menurut Sarwono dan Meinarno (2009) konformitas adalah kesesuaian antara perilaku seseorang dengan perilaku orang lain yang di dorong oleh keinginannya sendiri.

Comte (Taufik, 2012), mendefinisikan altruisme berasal dari kata alter yang artinya orang lain. Secara bahasa altruisme adalah perbuatan yang berorientasi pada kebaikan orang lain. Comte membedakan antara perilaku menolong yang altruis dengan perilaku menolong yang egois. Menurutnya dalam memberikan pertolongan, manusia memiliki dua motif, yaitu altruis dan egois. Kedua dorongan tersebut sama-sama ditujukan untuk memberikan pertolongan.

Sears et. al (1994) mendefinisikan altruisme adalah tindakan suka rela yang dilakukan oleh seseorang atau sekelompok orang untuk menolong orang lain tanpa mengharapkan imbalan apapun (kecuali mungkin perasaan telah melakukan kebaikan).

Taufik (2012) menjelaskan secara umum altruisme diartikan sebagai aktivitas menolong orang lain, yang dikelompokkan ke dalam perilaku prososial. Dikatakan perilaku prososial karena memiliki dampak positif terhadap orang lain atau masyarakat luas. Lawan dari perilaku prososial adalah perilaku antisosial, yaitu perilaku yang memiliki dampak buruk terhadap orang lain atau masyarakat, dan disebut juga dengan perilaku yang mengisolasi diri sendiri dari pergaulan lingkungan.

Titchner (dalam Goleman, 2003), menyatakan bahwa empati berasal dari semacam peniruan secara fisik atas beban orang lain, yang kemudian menimbulkan perasaan serupa dalam diri seseorang. Menurut Johnson (sebagaimana dikutip Sari \& Eliza, 2003), menyatakan bahwa empati adalah kecenderungan untuk memahami kondisi atau keadaan pikiran orang lain. Seseorang yang berempati digambarkan sebagai individu yang toleran, ramah, mampu mengendalikan diri, dan bersifat humanistik.

Taufik (2012) mendefinisikan empati merupakan suatu aktivitas untuk memahami apa yang sedang dipikirkan dan dirasakan orang lain, serta apa yang dipikirkan dan dirasakan oleh yang bersangkutan (observer, perceiver) terhadap kondisi yang sedang dialami orang lain tanpa yang bersangkutan kehilangan kontrol dirinya. Menurut Gunarsa (2000), menyatakan bahwa empati dianggap sebagai salah satu cara yang efektif dalam usaha mengenali, memahami, dan mengevaluasi orang lain. Dan hasil akhir yang terbaik dari empati adalah munculnya perilaku menolong, Warneken \& Tomasello (Taufik, 2012). Komunikasi dan bahasa, pengungkapan empati dipengaruhi oleh komunikasi (bahasa) yang digunakan seseorang. Perbedaan bahasa dan ketidakpahaman tentang komunikasi akan menjadi hambatan pada proses empati.

Batson, et. al (dalam Snyder dan Lopez, 2002) menyatakan bahwa altruisme mengacu pada bentuk spesifik dari motivasi memberikan manfaat pada organisme, biasanya manusia. Altruisme merupakan bentuk khusus dari motivasi dan istilah membantu untuk merujuk pada perilaku yang bermanfaat bagi orang lain. Sarwono (2002) menyatakan bahwa terdapat tiga macam norma sosial yang dijadikan pedoman untuk menolong, yaitu norma timbal balik, norma tanggung jawab, dan norma keseimbangan.

Batson (1943) menyatakan bahwa altruisme adalah keadaan termotivasi yang dilakukan untuk mencapai kesejahteraan orang lain. Bartal, dkk (dalam Desmita, 2010) mendefinisikan altruisme sebagai tahap dimana individu melakukan tindakan menolong secara sukarela. Tindakannya semata-mata hanya bertujuan menolong dan menguntungkan orang lain tanpa mengharapkan hadiah dari luar. Tindakan menolong dilakukan karena pilihannya sendiri dan didasarkan pada prinsip- 
prinsip moral. Sepanjang menyangkut keselamatan orang lain, individu dapat menilai kebutuhan orang lain, simpati kepada orang lain yang menderita dan membutuhkan bantuan, dan tidak mengharapkan keuntungan timbal balik untuk tindakannya.

$$
\text { Pillavin \& Chang (1990:71) }
$$
menyatakan bahwa aspek-aspek altruisme adalah: Menguntungkan orang lain, dilakukan secara sukarela, dilakukan secara sengaja, tujuan yang ingin dicapai harus bermanfaat, dan dilakukan tanpa mengharapkan imbalan apapun. Lead (dalam Desmita, 2010:19) menambahkan bahwa terdapat tiga kriteria dari tingkah laku altruistik, yaitu:
a. Tindakan yang bertujuan khusus menguntungkan orang lain tanpa mengharapkan reward eksternal.
b. Tindakan yang dilakukan dengan sukarela.
c. Tindakan yang menghasilkan sesuatu yang baik.

Berdasarkan pendapat dari beberapa ahli di atas dapat disimpulkan bahwa altruisme merupakan perilaku dan tindakan menolong yang memberi manfaat positif bagi yang ditolong, tidak mementingkan diri sendiri dan tanpa pamrih. Baron \& Byrne (2005) menyatakan bahwa altruisme mencakup beberapa aspek tindakan, antara lain berbagi, membantu orang lain, baik hati, dan kerja sama.

Rumusan masalah yang diajukan dalam penelitian ini adalah: Apakah Persepsi Kepemimpinan Kepala Sekolah berpengaruh langsung terhadap Altruistik guru di SMA Negeri 1 Sibolga?; Apakah Iklim Organisasi berpengaruh langsung terhadap Altruistik guru Di SMA Negeri 1 Sibolga?; Apakah Persepsi Kepemimpinan Kepala Sekolah berpengaruh langsung terhadap Disiplin Kerja guru Di SMA Negeri 1 Sibolga?; Apakah Iklim Organisasi berpengaruh langsung terhadap Disiplin Kerja guru di SMA Negeri 1 Sibolga?; Apakah Altruistik berpengaruh langsung terhadap Disiplin Kerja guru di SMA Negeri 1 Sibolga?

\section{METODE}

Teknik pengumpulan data yang digunakan dalam penelitian ini adalah survei ke lapangan dengan memberikan sejumlah kuesioner kepada guru yang dijadikan sebagai sampel penelitian sebagai responden. Tujuannya adalah untuk mengamati dan mengukur keempat variabel yang dijadikan penelitian ini, yaitu: persepsi tentang kepemimpinan kepala sekolah, iklim organisasi, altruistik, dan disiplin kerja guru. Teknik ini digunakan untuk memperoleh data primer yaitu data yang diperoleh langsung dari responden dengan cara mengisi kuesioner tersebut. Kuesioner penelitian ini terdiri dari pernyataanpernyataan untuk variabel-variabel persepsi tentang kepemimpinan kepala sekolah, iklim organisasi, altruistik, dan disiplin kerja guru.

Jenis penelitian ini adalah menggunakan paradigma kuantitatif dengan desain penelitian expost facto. Desain penelitian expost facto dilakukan dengan mengklasifikasikan variabel-variabel yang diteliti tidak dikendalikan dan dimanipulasi oleh peneliti, tetapi fakta diungkapkan berdasarkan pengukuran gejala yang telah dimiliki atau menguji apa yang akan terjadi. Menurut Hajar (1996:26), penelitian expost facto bertujuan untuk mengetahui apakah perbedaan yang terjadi antar kelompok subjek (dalam variabel independen) menyebabkan terjadinya perbedaan pada variabel dependent. Sedangkan metode penelitian yang digunakan adalah metode survei.

Model analisis jalur dibagi atas tiga bagian, yaitu: (1) correlated path model (model jalur korelasi); (2) mediated path model (model jalur mediasi); (3) independent path model (model jalur bebas). Jenis model dalam penelitian ini adalah mediated path model (model jalur mediasi). Penelitian ini menganalisis pengaruh satu variabel terhadap variabel lain, yaitu: (1) persepsi tentang kepemimpinan kepala sekolah, (2) iklim organisasi; (3) altruistik, dan (4) disiplin kerja.

Penelitian ini dilaksanakan di SMA Negeri 1 Sibolga, Kabupaten Sibolga, Provinsi Sumatera. Berdasarkan judul yang dikaji dalam penelitian ini, yakni: Hubungan persepsi kepemimpinan kepala sekolah, iklim organisasi dan altruistik dengan disiplin guru, yang dapat dikelompokkan menjadi dua bagian, yakni variabel bebas dan terikat. Variabel dalam penelitian ini adalah: (1) Persepsi guru tentang kepemimpinan kepala sekolah $\left(\mathrm{X}_{1}\right)$, iklim organisasi $\left(\mathrm{X}_{2}\right)$ dan altruistik $\left(\mathrm{X}_{3}\right)$, disiplin kerja guru (Y).

Kuesioner disusun berdasarkan konsep konstruk variabel yang terdiri dari empat bagian, yaitu: persepsi guru tentang kepemimpinan kepala sekolah, iklim organisasi, altruistik dan disiplin guru SMA Negeri 1 Sibolga. Masing-masing bagian berisi sejumlah pernyataan yang berhubungan dengan aspekaspek variabel yang diteliti. Pernyataan- 
pernyataan kuesioner variabel persepsi kepemimpinan kepala sekolah $\left(\mathrm{X}_{1}\right)$, iklim organisasi $\left(\mathrm{X}_{2}\right)$, altruistik $\left(\mathrm{X}_{3}\right)$, dan disiplin guru SMA Negeri 1 Sibolga terdiri dari pernyataan positif dan negatif.

Penyusunan kuesioner dilakukan dengan langkah-langkah sebagai berikut: (a) pembuatan kisi-kisi berdasarkan indikator dan deskriptor, (b) menyusun pernyataan atau item yang sesuai dengan kisi-kisi yang dibuat, dan (c) melakukan diskusi dan konsultasi dengan orang-orang yang ahli (pembimbing) agar diperoleh butir-butir yang memenuhi validitas isi (content validity).

Penyusunan butir-butir pernyataan kuesioner mempertimbangkan kemudahan pengisian oleh responden, sehingga penyusunannya memperhatikan beberapa hal penting, antara lain: (a) menghindari pernyataan yang meragukan atau ambigu, (b) menghindari kata-kata yang terlalu abstrak, (c) tidak menggunakan kata-kata yang mencurigakan atau ambigu.

Ada dua jenis uji instrumen yang digunakan dalam penelitian ini, yaitu uji keshahihan instrumen (validitas) dan uji kehandalan instrumen (reliabilitas).

Uji kesahihan instrumen dimaksudkan untuk mengetahui tingkat ketepatan instrumen yang akan digunakan. Uji keshahihan mencakup validitas isi (content validity), validitas logis (logical validity), validitas konstruk (construct validity), serta analisis butir. Dalam pelaksanaannya, dicari konsistensi internal dengan membuang butir-butir pernyataan yang lemah. Penyusunan kuesioner harus mempertimbangkan hal-hal sebagai berikut: (1) menghindari pernyataan yang meragukan atau tidak jelas, (2) menghindari penggunaan kata-kata yang dapat menimbulkan rasa curiga dan antipati.

Uji keterhandalan instrument merupakan tingkat konsistensi instrumen, di mana instrumen yang baik harus konsisten dengan variabel yang diukurnya. Analisis yang digunakan menggunakan teknik Alpha Cronbach .

\section{Data Statistik}

Adapun data statistik yang diajukan pada penelitian ini adalah:

1. Pengujian Penelitian Statistik 1

Penelitian yang diajukan adalah $\rho_{31}$ : Pengaruh langsung positif Persepsi Kepemimpinan Kepala Sekolah $\left(\mathrm{X}_{1}\right)$ terhadap Atruistik $\left(\mathrm{X}_{3}\right)$

$$
\begin{aligned}
& \text { Ho : } \rho_{31} \leq 0 \\
& \text { Ha }: \rho_{31}>0
\end{aligned}
$$

2. Pengujian Penelitian Statistik 2

Penelitian yang diajukan adalah $\rho_{32}$ :

Pengaruh langsung positif Iklim Organisasi $\left(\mathrm{X}_{2}\right)$ terhadap Atruistik $\left(\mathrm{X}_{3}\right)$.

$$
\begin{aligned}
& \text { Ho }: \rho_{32} \leq 0 \\
& \text { Ha }: \rho_{32}>0
\end{aligned}
$$

3. Pengujian Penelitian Statistik 3

Penelitian yang diajukan adalah $\rho_{41}$ : Pengaruh langsung positif Persepsi terhadap Kepemimpinan Kepala Sekolah sekolah $\left(\mathrm{X}_{1}\right)$ terhadap Disiplin Kerja $\left(\mathrm{X}_{4}\right)$.

$$
\begin{aligned}
& \text { Ho : } \rho_{41} \leq 0 \\
& \text { Ha }: \rho_{41}>0
\end{aligned}
$$

4. Pengujian Penelitian Statistik 4

Penelitian yang diajukan adalah $\rho_{42}$ : Pengaruh langsung positif Iklim Organisasi $\left(\mathrm{X}_{2}\right)$ terhadap Disiplin Kerja $\left(\mathrm{X}_{4}\right)$.

$$
\begin{aligned}
& \text { Ho }: \rho_{42} \leq 0 \\
& \text { Ha }: \rho_{42}>0
\end{aligned}
$$

5. Pengujian Penelitian Statistik 5

Penelitian yang diajukan adalah $\rho_{43}$ : Pengaruh langsung positif Altruistik guru $\left(\mathrm{X}_{3}\right)$ terhadap Disiplin Kerja guru $\left(\mathrm{X}_{4}\right)$.

$$
\begin{aligned}
& \text { Ho : } \rho_{43} \leq 0 \\
& \text { Ha : } \rho_{43}>0
\end{aligned}
$$

\section{Keterangan:}

$$
\begin{aligned}
& \text { Ho }=\text { Penelitian nol } \\
& \mathrm{Ha}=\text { Penelitian alternaltif } \\
& \rho_{31}=\text { Koefisien jalur antara Persepsi }
\end{aligned}
$$

\section{HASIL PENELITIAN DAN PEMBAHASAN}

Penelitian ini menggunakan model pembinaan melalui supervisi manajerial. Tujuan yang diharapkan pada pertemuan pertama dalam pembinaan melalui supervisi manajerial ini adalah Peningkatan kinerja Guru. 
Pelaksanaan tindakan dalam penelitian dilakukan 3 kegiatan penelitian yang terdiri dari tiga kali pertemuan. Waktu yang digunakan setiap kali pertemuan adalah 2 x 60 menit untuk tiap Kelompok Guru. Penelitian tindakan sekolah untuk Guru ini dilaksanakan sesuai dengan prosedur rencana pembinaan dan skenario, serta surat tugas yang diberikan

Berikut hasil pembinaan melalui supervisi manajerial per-kegiatan sebagai berikut:

\section{Kegiatan Penelitian 1}

Tahap Perencanaan

Pada tahap ini peneliti mempersiapkan perangkat pembinaan yang terdiri dari rencana pembinaan, soal tes formatif 1 dan alat-alat pembinaan lain yang mendukung. Selain itu juga dipersiapkan lembar observasi peningkatan kinerja dengan pemberian balikan.

Tahap Kegiatan dan Pelaksanaan

Pelaksanaan kegiatan pembinaan untuk kegiatan penelitian I dilaksanakan pada tanggal 5 s.d 10 Februari 2018 di SMA Negeri 1 Sibolga. Dalam hal ini peneliti bertindak sebagai Pembina guru. Adapun proses pembinaan mengacu pada rencana pembinaan yang telah dipersiapkan.

Pengamatan (observasi) dilaksanakan bersamaan dengan pelaksanaan pembinaan di sekolah. Pada akhir proses pembinaan Kelompok Guru diberi tes formatif I dengan tujuan untuk mengetahui tingkat keberhasilan Kelompok Guru dalam meningkatkan kinerjanya sesuai dengan yang telah dilakukan. Adapun data hasil penelitian pada kegiatan penelitian I. adalah seperti pada tabel berikut :

Tabel 1. Tabel Distribusi Nilai tes Pada Kegiatan Penelitian I

\begin{tabular}{llccc}
\hline & & \multicolumn{2}{c}{ Keterangan } \\
\cline { 3 - 5 } N & Nama & Skor & $\begin{array}{l}\text { Tunt } \\
\text { as }\end{array}$ & $\begin{array}{l}\text { Tidak } \\
\text { Tunta } \\
\text { s }\end{array}$ \\
\hline 1 & Kelompok Guru 1 & 80 & $\sqrt{ }$ & - \\
2 & Kelompok Guru 2 & 60 & - & $\sqrt{ }$ \\
3 & Kelompok Guru 3 & 40 & - & $\sqrt{ }$ \\
4 & Kelompok Guru 4 & 70 & $\sqrt{ }$ & - \\
\hline Jumlah Total & $\mathbf{2 5 0}$ & - & - \\
\hline $\begin{array}{l}\text { Skor Maksimum } \\
\text { Individu }\end{array}$ & $\mathbf{1 0 0}$ & - & - \\
\hline $\begin{array}{l}\text { Skor maksimum } \\
\text { Kelompok Kelompok }\end{array}$ & $\mathbf{3 0 0}$ & - & - \\
Guru (SMA ) & & & \\
\hline
\end{tabular}

\section{Keterangan :}

Jumlah Kelompok Guru yang tuntas

: 1 Kelompok

Jumlah Kelompok Guru yang belum tuntas

: 2 Kelompok

Kriteria Kelompok Guru

: belum tuntas.

Dari tabel di atas dapat dijelaskan bahwa dengan pembinaan yang dilakukan oleh Pembina melalui supervisi manajerial diperoleh nilai rata-rata peningkatan kinerja Kelompok Guru adalah $60 \%$ atau ada 2 Kelompok Guru dari 3 orang sudah tuntas. Hasil tersebut menunjukkan bahwa pada kegiatan penelitian pertama secara kelompok kepala SMA belum meningkat kinerjanya, karena yang memperoleh nilai $\geq 65$ hanya sebesar 33,3\% lebih kecil dari persentase ketuntasan yang dikehendaki yaitu sebesar 85 $\%$. Hal ini disebabkan karena 2 Kelompok Guru yang baru diangkat/dilantik menjadi Kelompok Guru sehingga mereka merasa baru dengan tugas tersebut.

a. Penilaian/Umpan Balik

Dalam pelaksanaan kegiatan pembinaan diperoleh informasi dari hasil pengamatan sebagai berikut:

1) Pembina masih kurang teliti dalam melakukan pembinaan di sekolah

2) Pembina masih kurang baik dalam pemanfaat waktu

3) Pembina Sekolah masih kurang konsentrasi dalam melakukan pembinaan, karena ada trugas lain yang harus dikerjakan.

Revisi Rancangan

Pelaksanaan kegiatan pembinaan pada kegiatan penelitian pertama ini masih terdapat kekurangan, sehingga perlu adanya revisi untuk dilakukan pada kegiatan penelitian berikutnya.

1) Pembina perlu lebih terampil dalam memotivasi Kelompok Guru dan lebih jelas dalam menyampaikan tujuan pembinaan. Di mana Kelompok Guru diajak untuk terlibat langsung dalam setiap kegiatan yang akan dilakukan.

2) Pembina perlu mendistribusikan waktu secara baik dengan menambahkan informasi-informasi yang dirasa perlu dan memberi catatan

3) Pembina harus lebih terampil dan bersemangat dalam memotivasi Kelompok Guru sehingga kinerjanya lebih meningkat. 


\section{Kegiatan Penelitian II}

Tahap perencanaan

Pada tahap ini peneliti mempersiapkan perangkat pembinaan yang terdiri dari rencana Pembinaan 2, soal tes formatif II dan alat-alat Pembinaan lain yang mendukung.

Tahap kegiatan dan pelaksanaan

Pelaksanaan kegiatan pembinaan supervisi manajerial untuk kegiatan penelitian II dilaksanakan pada tanggal 21 Februari s.d 29 Februari 2018 di SMA Negeri 1 Sibolga Tahun Pelajaran 2017/2018. Dalam hal ini peneliti bertindak sebagai Supervisor. Adapun proses pembinaan mengacu pada rencana pembinaan dengan memperhatikan revisi pada kegiatan penelitian I, sehingga kesalahan atau kekurangan pada kegiatan penelitian I tidak terulang lagi pada kegiatan penelitian II. Penelitian tindakan sekolah ini dilaksanakan sesuai dengan prosedur rencana pembinaan.

Pada akhir proses pembinaan Kelompok Guru diberi tes formatif II dengan tujuan untuk mengetahui tingkat keberhasilan Kelompok Guru dalam meningkatkan kinerjanya. Instrumen yang digunakan adalah tes formatif II. Adapun data hasil penelitian pada kegiatan penelitian II adalah sebagai berikut:

Tabel 2. Tabel Distribusi Nilai tes Pada Kegiatan Penelitian II

\begin{tabular}{llccc}
\hline & & \multicolumn{2}{c}{ Keterangan } \\
\cline { 3 - 5 } No & Nama & Skor & $\begin{array}{l}\text { Tun } \\
\text { tas }\end{array}$ & $\begin{array}{l}\text { Tidak } \\
\text { Tunta } \\
\text { sund }\end{array}$ \\
\hline 1 & Kelompok Guru 1 & 90 & $\sqrt{c}$ & - \\
2 & Kelompok Guru 2 & 85 & $\sqrt{ }$ & - \\
3 & Kelompok Guru 3 & 60 & - & $\sqrt{ }$ \\
$4 \quad$ Kelompok Guru 4 & 80 & $\sqrt{ }$ & - \\
\hline Jumlah Total & $\mathbf{3 1 5}$ & - & - \\
\hline $\begin{array}{l}\text { Skor Maksimum } \\
\text { Individu }\end{array}$ & $\mathbf{1 0 0}$ & - & - \\
\hline $\begin{array}{l}\text { Skor maksimum } \\
\text { Kelompok Kelompok }\end{array}$ & $\mathbf{3 0 0}$ & - & - \\
Guru (SMA ) & & & \\
\hline
\end{tabular}

Keterangan :

Jumlah Kelompok Guru yang tuntas

$$
\text { : } 2 \text { Kelompok }
$$

Jumlah Kelompok Guru yang belum tuntas : 1 Kelompok

Kriteria Kelompok Guru : belum tuntas.
Dari tabel di atas diperoleh nilai ratarata peningkatan kinerja Kelompok Guru adalah $60,00 \%$ dan peningkatan kinerja mencapai $78,00 \%$ atau ada 11 orang dari 3 orang Kelompok Guru yang sudah tuntas dalam meningkatkan kinerjanya. Hasil ini menunjukkan bahwa pada kegiatan penelitian II ini peningkatan kinerja Kelompok Guru telah mengalami peningkatan sedikit lebih baik dari kegiatan penelitian I. Adanya peningkatan kinerja Kelompok Guru ini karena setelah Pembina telah menginformasikan bahwa setiap akhir pembinaan akan diadakan penilaian sehingga pada pertemuan berikutnya Kelompok Guru lebih termotivasi untuk meningkatkan kinerjanya. Selain itu Kelompok Guru juga sudah mulai mengerti apa yang dimaksudkan dan diinginkan oleh Pembina dalam melakukan pembinaan melalui supervisi manajerial.

\section{a. Penilaian/Umpan Balik}

Dalam pelaksanaan pembinaan diperoleh informasi dari hasil pengamatan sebagai berikut:

1) Memotivasi Kelompok Guru

2) Membimbing Kelompok Guru dalam menyusun rencana kerja sekolah merumuskan kesimpulan/menemukan konsep

3) Pengelolaan waktu

b. Revisi Pelaksanaaan

Pelaksanaan pembinaan pada kegiatan penelitian II ini masih terdapat kekurangankekurangan. Maka perlu adanya revisi untuk dilaksanakan pada kegiatan penelitian III antara lain:

1) Pembina dalam memberikan pembinaan kepada Kelompok Guru hendaknya dapat membuat Kelompok Guru termotivasi dalam membuat program dan rencana sekolah.

2) Pembina harus lebih dekat dengan Kelompok Guru sehingga tidak ada perasaan takut/malu dalam diri Kelompok Guru terutama dalam bertanya tentang masalah yang dihadapi oleh sekolah.

3) Pembina harus lebih sabar dalam melakukan pembinan kepada Kelompok Guru terutama dalam merumuskan kesimpulan/menemukan konsep.

4) Pembina harus mendistribusikan waktu secara baik sehingga kegiatan pembinaan dapat berjalan efektif sesuai dengan yang diharapkan.

5) Pembina sebaiknya menambah lebih banyak contoh contoh program kerja 
dengan format format yang sudah distandardisasi oleh Departemen Pendidikan dan Kebudayaan.

\section{Kegiatan Penelitian III}

Tahap Perencanaan

Pada tahap ini peneliti mempersiapkan perangkat pembinaan yang terdiri dari rencana pembinaan 3 , soal tes formatif 3 dan alat-alat pembinaan lainnya

Tahap kegiatan dan pengamatan

Pelaksanaan pembinaan untuk kegiatan penelitian III dilaksanakan pada tanggal 8 s.d 15 Maret 2018 di SMA Negeri 1 Sibolga Tahun Pelajaran 2017/2018 dengan jumlah 3 orang Kelompok Guru. Dalam hal ini peneliti bertindak sebagai Pembina. Adapun proses pembinaaan mengacu pada rencana pembinaan dengan memperhatikan revisi pada kegiatan penelitian II, sehingga kesalahan atau kekurangan pada kegiatan penelitian II tidak terulang lagi pada kegiatan penelitian III. Pengamatan (observasi) dilaksanakan bersamaan dengan pelaksanaan tugas supervisi yang diberikan.

Pada akhir proses pembinaan Kelompok Guru diberi tes formatif III dengan tujuan untuk mengetahui tingkat keberhasilan Kelompok Guru dalam meningkatkan kinerjanya yang telah dilakukan. Instrumen yang digunakan adalah tes formatif III. Adapun data hasil penelitian pada kegiatan penelitian III adalah sebagai berikut :

Tabel 3. Tabel Distribusi Nilai tes Pada Kegiatan Penelitian III

\begin{tabular}{|c|c|c|c|c|}
\hline \multirow[b]{2}{*}{$\begin{array}{l}\mathbf{N} \\
\mathbf{0}\end{array}$} & \multirow[b]{2}{*}{ Nama } & \multirow[b]{2}{*}{$\begin{array}{l}\text { Sk } \\
\text { or }\end{array}$} & \multicolumn{2}{|c|}{ Keterangan } \\
\hline & & & $\begin{array}{l}\text { Tu } \\
\text { nta } \\
\text { S }\end{array}$ & $\begin{array}{l}\text { Tdk } \\
\text { Tunta } \\
\text { S }\end{array}$ \\
\hline 1 & Kelompok Guru 1 & 100 & $\sqrt{ }$ & - \\
\hline 2 & Kelompok Guru 2 & 95 & $\sqrt{ }$ & - \\
\hline 3 & Kelompok Guru 3 & 90 & $\sqrt{ }$ & - \\
\hline 4 & Kelompok Guru 4 & 90 & $\sqrt{ }$ & - \\
\hline \multicolumn{2}{|c|}{ Jumlah Total } & 375 & - & - \\
\hline \multicolumn{2}{|c|}{$\begin{array}{ll}\text { Skor } & \text { Maksimum } \\
\text { Individu } & \end{array}$} & 100 & - & - \\
\hline & $\begin{array}{l}\text { rmaksimum } \\
\text { ompok Guru ( } \\
\text { A ) }\end{array}$ & 300 & - & - \\
\hline
\end{tabular}

Keterangan :

Jumlah Kelompok Guru yang tuntas : 4 Orang
Jumlah Kelompok Guru yang belum tuntas : - Orang

Kriteria Kelompok Guru : Sudah tuntas.

Berdasarkan tabel di atas diperoleh nilai rata-rata tes formatif sebesar $95 \%$ dan dari 3 Kelompok Guru secara keseluruhan sudah mencapai ketuntasan dalam meningkatkan kinerjanya. Maka secara kelompok ketuntasan telah mencapai $100 \%$ ( termasuk kategori tuntas). Hasil pada kegiatan penelitian III ini mengalami peningkatan lebih baik dari kegiatan penelitian II. Adanya peningkatan hasil pembinaan pada kegiatan penelitian III ini dipengaruhi oleh adanya peningkatan kemampuan Pembina dalam menerapkan pembinaan melalui supervisi manajerial sehingga Kelompok Guru menjadi lebih memahami tugasnya sehingga dapat meningkatkan kinerjanya. Di samping itu ketuntasan ini juga dipengaruhi oleh kerja sama dari Kelompok Guru dengan Pembina dalam merencanakan program kerja sekolahnya masing masing.

Penilaian/Umpan Balik

Pada tahap ini akan dikaji apa yang telah terlaksana dengan baik maupun yang masih kurang baik dalam proses pembinaan melalui supervisi manajerial. Dari data-data yang telah diperoleh dapat duraikan sebagai berikut:

1) Selama proses pembinaan Pembina telah melaksanakan semua pembinaan dengan baik. Meskipun ada beberapa aspek yang belum sempurna, tetapi persentase pelaksanaannya untuk masing-masing aspek cukup besar.

2) Berdasarkan data hasil pengamatan diketahui bahwa Kelompok Guru aktif selama proses pembinaan berlangsung.

3) Kekurangan pada kegiatan penelitian sebelumnya sudah mengalami perbaikan dan peningkatan sehingga menjadi lebih baik.

4) Hasil pembinaan Kelompok Guru oleh Pembina melalui supervisi manajerial pada kegiatan penelitian III mencapai ketuntasan.

Revisi Pelaksanaan

Pada kegiatan penelitian III Pembina telah melaksanakan pembinaan dengan baik dan dilihat dari peningkatan kinerja Kelompok Guru pelaksanaan pembinaan sudah berjalan dengan baik. Maka tidak diperlukan revisi terlalu 
banyak, tetapi yang perlu diperhatikan untuk tindakan selanjutnya adalah memaksimalkan dan mempertahankan apa yang telah ada dengan tujuan agar pada pelaksanaan pembinaan selanjutnya baik melalui supervisi manajerial maupun supervisi akademik dapat meningkatkan kinerja Kelompok Guru sehingga tujuan pembinaan sebagai upaya meningkatkan mutu pendidikan dapat tercapai.

\section{Analisis Hasil Kegiatan}

Setelah dilakukan tindakan pada kegiatan penelitian 1, kegiatan penelitian 2 dan kegiatan penelitian 3 menunjukkan hasil sebagai berikut.

Tabel 4. Analisis Hasil Tes Tentang Pembinaan Terhadap Peningkatan Kinerja Kelompok Guru dalam Menyusun Rencana Kerja

\begin{tabular}{llccc}
\hline No & Nama & $\begin{array}{c}\text { Skor sebelum } \\
\text { Tindakan } \\
\text { Kegiatan 1 }\end{array}$ & $\begin{array}{c}\text { Skor setelah } \\
\text { Tindakan 1 } \\
\text { Kegiatan 2 }\end{array}$ & $\begin{array}{c}\text { Skor setelah } \\
\text { Tindakan 2 } \\
\text { Kegiatan 3 }\end{array}$ \\
\hline 1 & Kelompok Guru 1 & 80 & 90 & 100 \\
2 & Kelompok Guru 2 & 60 & 85 & 95 \\
3 & Kelompok Guru 3 & 40 & 60 & 90 \\
4 & Kelompok Guru 4 & 70 & 80 & 90 \\
\hline Jumlah Total & $\mathbf{2 5 0}$ & $\mathbf{3 1 5}$ & $\mathbf{3 8 5}$ \\
\hline Rerata & $\mathbf{6 2 . 5}$ & $\mathbf{7 8 . 7 5}$ & $\mathbf{9 6 . 2 5}$ \\
\hline Skor Maksimum Individu & $\mathbf{1 0 0}$ & $\mathbf{1 0 0}$ & $\mathbf{1 0 0}$ \\
\hline Skor Maksimum Kelas & $\mathbf{3 0 0}$ & $\mathbf{3 0 0}$ & $\mathbf{3 0 0}$ \\
\hline Prosentasi Peningkatan & $\mathbf{6 0 . 0}$ & $\mathbf{7 8 . 6}$ & $\mathbf{9 5 . 0}$ \\
\hline
\end{tabular}

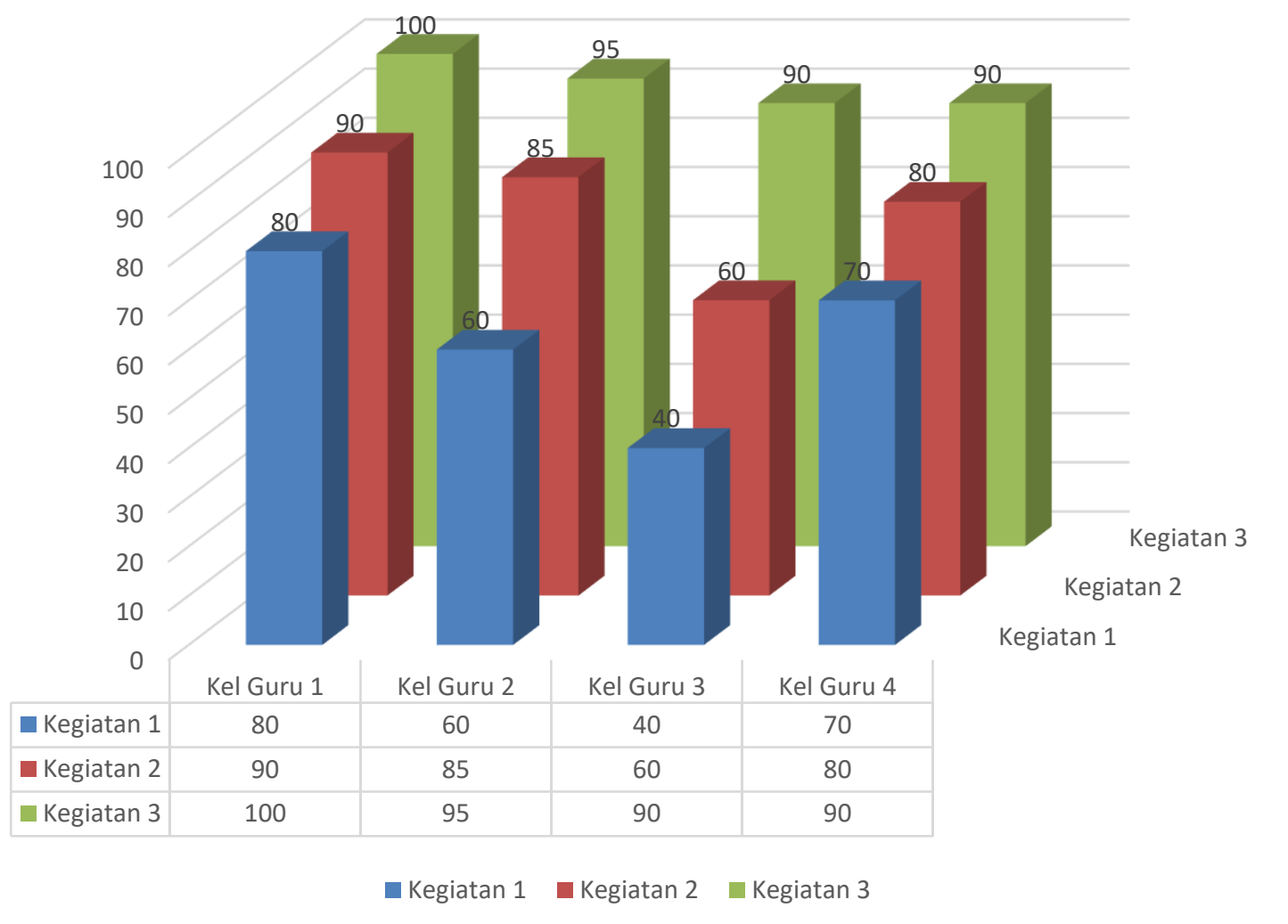

Gambar 1. Diagaram Analisis Hasil Tes

Kelompok Guru

Pembinaan Terhadap Peningkatan Kinerja 
Dari hasil analisis tersebut dapat disimpulkan bahwa

a. Pada kegiatan penelitian ke 1 setelah diberikan informasi dan diskusi kinerja Kelompok Guru rerata 60. Atau $60 \%$ dibandingkan kinerja ideal, dan masih ada 2 orang belum tuntas,

b. Pada kegiatan penelitian ke 2 setelah dengan perbaikan pembinaan rerata kinerja kepsek menjadi 78.33, terdapat peningkatan sebesar 18.33 dari kegiatan penelitian pertama atau sebesar $78.3 \%$ dibandingkan dengan kinerja ideal. Dan masih

c. Pada kegiatan penelitian ke 3 setelah dengan perbaikan pembinaan rerata kinerja kepsek menjadi 95.55, terdapat peningkatan sebesar 18.33 dari kegiatan penelitian kedua atau sebesar $78.3 \%$ dibandingkan dengan kinerja ideal.

d. Dari sebelum pembinaan (kegiatan penelitian 1) dan setelah pembinaan oleh Pembina sampai dengan (kegiatan penelitian 3) $60.00 \%$ menjadi $95.00 \%$, dan dari (kegiatan penelitian 2) ke (kegiatan penelitian 3) juga ada peningkatan sebanyak $78.33 \%-95.00 \%$ $=16,67 \%$.

e. Rata-rata kinerja Kelompok Guru sebelum diberi pembinaan 60 naik 35.00 menjadi 95,00

f. Dari Pembinaan pada kegiatan penelitian 2 dan setelah pembinaan melalui supervisi manajerial (kegiatan penelitian 3) 76,33\% menjadi $88 \%$ berarti ada peningkatan prestasi sebanyak $88 \%-76,33 \%=11,67$ $\%$

\section{Penilaian/Umpan Balik dan Temuan dalam Penelitian}

Berdasarkan pelaksanaan pembinaan yang telah dilakukan Pembina kepada Kelompok Guru melalui pembinaan supervisi manajerial maka hasil observasi nilai, dapat dikatakan sebagai berikut:

a. Pertemuan pertama kegiatan pembinaan belum berhasil karena dalam pembinaan Pembina masih terlihat Kelompok Guru belum begitu antusias karena mereka masih menganggap pembinaan Pembina tersebut merupakan tugas baru yang diembannya ;

b. Pembinaan yang dilakukan Pembina melalui supervisi manajerial, dalam hal
Peningkatan kinerja Kelompok Guru dalam Menyusun Rencana Kerja belum tampak, sehingga hasil yang dicapai tidak tuntas.

c. Mungkin karena proses pembinaan yang dilakukan Pembina melalui supervisi manajerial yang baru mereka laksanakan sehingga Kelompok Guru merasa kaku dalam menerapkannya.

d. Akan tetapi setelah dijelaskan, mereka bisa mengerti dan buktinya pada pertemuan kedua dan ketiga proses pembinaan Pembina berjalan baik, semua Kelompok Guru aktif dan lebih-lebih setelah ada rubrik penilaian proses, semua Kelompok Guru antusias untuk mengikutinya.

\section{Pembahasan Hasil Penelitian}

a. Ketuntasan Hasil Pembinaan Kinerja Kelompok Guru

Melalui hasil penelitian ini menunjukkan bahwa pembinaan Pembina melalui supervisi manajerial memiliki dampak positif dalam meningkatkan kinerja Kelompok Guru, hal ini dapat dilihat dari semakin mantapnya pemahaman Kelompok Guru terhadap pembinaan yang disampaikan Pembina (kinerja Kelompok Guru dalam Menyusun Rencana Kerja terdapat peningkatan dari kegiatan penelitian I, II, dan III ) yaitu masing-masing $60 \%$; 78,33 $\%$; $95 \%$ pada kegiatan penelitian III kinerja Kelompok Guru secara kelompok dikatakan tuntas.

b. Kemampuan Pembina meningkatkan kinerja Kelompok Guru dalam Menyusun Rencana Kerja

Berdasarkan analisis data, diperoleh aktivitas Kelompok Guru dalam meningkatkan kinerjanya dalam setiap kegiatan penelitian mengalami peningkatan. Hal ini berdampak positif terhadap kinerja Kelompok Guru yaitu dapat ditunjukkan dengan meningkatnya nilai rata-rata Kelompok Guru pada setiap kegiatan penelitian yang terus mengalami peningkatan.

c. Aktivitas Pembina dan Kelompok Guru dalam Pembinaan melalui Supervisi Manajerial

Berdasarkan analisis data, diperoleh aktivitas Pembina dan Kelompok Guru yang paling dominan dalam kegiatan supervisi manajerial adalah bekerja dengan menggunakan alat/media, mendengarkan/ 
memperhatikan penjelasan Pembina, dan diskusi antar antar Kelompok Guru dan Pembina. Jadi dapat dikatakan bahwa aktivitas Kelompok Guru dapat dikategorikan aktif.

Sedangkan untuk aktivitas Pembina selama pembinaan telah melaksanakan langkahlangkah metode pembinaan melalui supervisi manajerial dengan baik. Hal ini terlihat dari aktivitas Kelompok Guru yang muncul di antaranya aktivitas membuat dan merencanakan program sekolah, melaksanakan, memberi umpan balik/evaluasi/tanya jawab di mana prosentase untuk aktivitas di atas cukup besar.

Berdasarkan hasil penelitian di atas, Peningkatan kinerja Kelompok Guru dalam Menyusun Rencana Kerja melalui pembinaan supervisi manajerial Pembina hasilnya sangat baik. Hal itu tampak pada pertemuan pertama dari 3 orang Kelompok Guru yang ada pada saat penelitian ini dilakukan nilai rata rata mencapai ; $60 \%$ meningkat menjadi 78,33\% dan pada kegiatan penelitian 3 meningkat menjadi $95 \%$.

Dari analisis data di atas bahwa pembinaan kinerja Pembina melalui supervisi manajerial efektif diterapkan dalam upaya meningkatkan kinerja Kelompok Guru dalam menyusun Rencana Kerja, yang berarti proses pembinaan Pembina lebih berhasil dan dapat meningkatkan kinerja Kelompok Guru khususnya di SMA Negeri 1 Sibolga, oleh karena itu diharapkan kepada para Pembina dapat melaksanakan pembinaan melalui pembinaan dan manajerial secara berkelanjutan.

\section{PENUTUP}

Berdasarkan hasil analisa data dan pengajuan penelitian, maka dapat diambil kesimpulan sebagai berikut:

1) Terdapat pengaruh langsung yang signifikan kepemimpinan kepala sekolah terhadap altruistik guru SMA di SMA Negeri 1 Sibolga. Dengan perkataan lain, semakin baik persepsi terhadap kepemimpinan kepala sekolah, semakin baik altruistik Guru SMA di Kota Medan.

2) Terdapat pengaruh langsung yang signifikan iklim organisasi terhadap altruistik guru di SMA Negeri 1 Sibolga. Dengan perkataan lain, semakin baik iklim organisasi, semakin baik altruistik Guru SMA di SMA Negeri 1 Sibolga.

3) Terdapat pengaruh langsung yang signifikan kepemimpinan kepala sekolah terhadap disiplin kerja guru guru di SMA Negeri 1 Sibolga. Dengan perkataan lain, semakin baik persepsi terhadap kepemimpinan kepala sekolah, semakin baik disiplin kerja Guru SMA di SMA Negeri 1 Sibolga.

4) Terdapat pengaruh langsung yang signifikan iklim organisasi terhadap disiplin kerja guru di SMA Negeri 1 Sibolga. Dengan perkataan lain, semakin baik iklim organisasi, semakin baik disiplin kerja Guru SMA di SMA Negeri 1 Sibolga.

5) Terdapat pengaruh pengaruh langsung yang signifikan altruistik terhadap disiplin kerja guru di empat SMA Kota Medan. Dengan perkataan lain, semakin baik altruistik guru, semakin baik

\section{DAFTAR PUSTAKA}

Anwar Idochi, M. 2003. Administrasi Pendidikan dan Manajemen Biaya Pendidikan, Teori, Konsep, dan Isu. Bandung : Alfabeta.

Arikunto, Suharsimi. 1999. Prosedur Penelitian Suatu Pendekatan Praktek. Jakarta : Rineka Cipta.

Borich, GD, 1994. Observation Skill For Effective Teaching, New York : Macmillan Publishing Company

Bush, Tong and Coleman, Marianne. 2000. Leadership and Strategic Management in Education. London : Sage Publications Company.

Depdiknas RI 2007, Peraturan No 12 Tentang Kompetensi Pengawas.Jakarta : Depdiknas

2007, Peraturan Menteri No 13 Tentang Kompetensi Kepala Sekolah.Jakarta : Depdiknas. 2007, Peraturan Menteri No 19 Tentang Standar Pengelolaan Sekolah/Madrasah.Jakarta : Depdiknas

Caroll, Kennedy. 1996. Managing with The Gurus. London : All Rights Reserved.

Chery, Yin Cheung. 1996. School Effectiveness \& School Based Management : A Mechanism for Development. Washington DC. The Falmer Press.

Dahar, RW. 1988. Teori-Teori Belajar. Jakarta : Direktorat Dikti, Proyek Kerja Lembaga Tenaga Kependidikan.

Danin, Sudarwan. 2000. Pengantar Studi Penelitian Kebijakan. Jakarta : Bumi Aksara 
Depdiknas. 2002. Kebijakan Direktorat Pendidikan Lanjutan Pertama. Jakarta : Direktorat Dikdasmen.

. 2002. Rencana dan Program Pelaksanaan MPMBS ; Jakarta : Direktorat Dikdasmen . 2002. Konsep Dasar MPMBS.

Jakarta : Direktorat Dikdasmen 2002. Pedoman Tatakrama dan Tata Tertib Kehidupan Sosial Sekolah Bagi SLTP. Jakarta : Direktorat Dikdasmen 2002. Pembelajaran Dan Pengajaran Kontektual. Jakarta : Direktorat Dikdasmen . 2002. Panduan Monitoring dan Evaluasi. Jakarta : Direktorat Dikdasmen .2002. Kurikulum Berbasis Kompetensi. Jakarta : Pusat Kurikulum Balitbang Depdiknas 2003. Undang-Undang No 20 Tahun 2003 Tentang Sistem Pendidikan Nasional. Bandung : Citra Umbara

Dirjen PMPTK 2009,Bahan Belajar Mandiri Dimensi Kompetensi Supervisi Manajerial.Jakarta : Dirjen PMPTK Depdiknas.

Duhou, Abu Ibtisan. 1999. School-Based Management. Paris : Unesco International Institue for Educational Planning.

Echols.MJ, Shadily.H 2000.Kamus Inggeris Indonesia , Jakarta : PT. Gramedia PustakaUtama

Faisal, Sanapiah, 1989. Format-format Penelitian Sosial Dasar-dasar dan Aplikasi. Penerbit: Jakarta : CV.
Rajawali.

Gibson, Rowan, 1997. Rethingking The Future Rethingking Business, Principles, Competition, Control, Leadership, Markets and The World. Copyright Jakarta : PT. Gramedia Pustaka Utama.

Hadi Sutrisno, 1984. Metodologi Reseach. Yogyakarta : Yayasan Penerbit Fakultas Psikologi UGM.

Handoko TH, 1995.Manajemen dan Sumber Daya Manusia. Yogyakarta: BPFE

Ibrahim, MS. 2003. Pengajaran Langsung. Jakarta : Direktorat Dikdasmen Depdiknas RI

Mudjiono, Dimyati. 2002. Belajar dan Pembelajaran. Jakarta : Rineka Cipta

Mulyasa E, 2002. Manajemen Berbasis Sekolah. Konsep, Stragtegi, dan Implementasi. Bandung : PT. Remaja Rosdakarya. 2003. Menjadi Kepala Sekolah Profesional dalam Konteks Menyukseskan MBS dan MBK, Bandung :PT. Remaja Rosdakarya.

Nurkancana, Wayan Sumartana, 1992. Evaluasi Pendidikan, Surabaya : Penerbit Usaha Nasional

Owen, Robert G. 1981. Organizational Behavior of Education. New Jersey : Prentice-Hall, Inc. Englewood Cliffs.

Pidarta, Made . 1990. Perencanaan Pendidikan Partisipatori. Jakarta : Rineka Cipta 1997. Landasan Kependidikan Stimulus Ilmu Pendidikan Bercorak Indonesia. Jakarta : Rineka Cipta 